\title{
AMELIORATIVE EFFECT OF PUMPKIN SEED OIL AGAINST THE BISPHENOL-A ADVERSE EFFECTS IN MALE MICE. BY \\ ${ }^{1}$ F.I. Eissa, ${ }^{2}$ A.I. El Makawy, ${ }^{1}$ M.M. EL-BAMBY and ${ }^{1}$ O.H. Elhamalawy FROM \\ ${ }^{1}$ Department of Environment and Bio-Agriculture, Faculty of Agriculture, Al-Azhar University, , Cairo, Egypt. \\ ${ }^{2}$ Department of Cell Biology, National Research Center, Dokki, Giza, Egypt.
}

\begin{abstract}
The present study was conducted to evaluate the ameliorative role of pumpkin seed oil (PSO) against potential adverse effects of bisphenol-A (BPA) in male mice. BPA was administered to the mice orally at a dose of $50 \mathrm{mg} / \mathrm{kg}$ body weight once a day for 28 successive days. While, PSO was administered to the mice orally at $1 \mathrm{~mL} / \mathrm{kg} \mathrm{b} . \mathrm{w}$. either before, with or after treatment of BPA, once a day for 28 successive days. The studied parameters were DNA damage evaluation using comet assay in liver and testes cells and micronucleus test in bone marrow; and histopathological examination of liver and testes tissues. Results revealed that BPA induced DNA damage in tested cells and marked histopathological alterations in liver and testes. In contrast, PSO treatments alleviated DNA damage and improved the histopathological alterations in liver and testes tissues. Furthermore, administration of mice with the PSO before BPA treatment was the best regimen in the alleviation of the adverse effects of BPA, followed by administration of PSO after then with treatment of BPA. It can be concluded that PSO may has a protective role against BPA genotoxicity and histopathological alterations in male mice.
\end{abstract}

\section{Key words:}

Pumpkin seed oil; Bisphenol-A; Genotoxicity; Micronucleus; Comet assay; Histopathology. 


\section{Introduction:}

Among the various endocrine disrupting chemicals (EDCs), bisphenol-A (BPA) is the most important man-made compound with annual production exceeding 3.8 million tons (Michalowicz, 2014). It is a synthetic monomer used in production of polycarbonate plastics, epoxy resins, food packaging, dental sealant, water pipes, toys, fire retardant, plastic bottles, paints, pesticides and lacquers for food cans (Burridge, 2003; Fleisch et al., 2010).

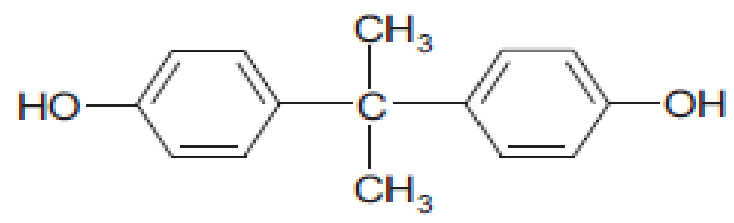

Fig. 1: Chemical structure of bisphenol-A (BPA)

Biomonitoring studies supported the widespread exposure to BPA (Calafat $\boldsymbol{e t}$ al., 2008; Fu and Kawamura, 2010); and the potential human threat from usage of these products awing to the ability of BPA to leach out of plastics into the food and beverages they contain (Berger et al., 2016). BPA causes hepatotoxic, mutagenic, reproductive and carcinogenic effects (Doherty et al., 2010; Erler and Novak, 2010; Meeker et al., 2010; Zeinab et al., 2012). Several studies confirmed the genotoxicity of BPA (Kalb et al., 2015; Xin et al., 2015). In addition, growing evidence indicated that the oxidative stress caused by BPA could be one of the mechanisms leading to this toxicity (Meeker et al., 2010; Tiwari et al., 2012).

Natural antioxidants play a main role to diminish the oxidative stress by scavenging the free radicals and by further mechanisms which can prevent a variety of diseases (Ahmad et al., 2012). The prevention of BPA-induced toxicity has been shown by using of antioxidants such as vitamin A (Aikawa et al., 2004) vitamin C (Korkmaz et al., 2010), pomegranate juice (El Ghazzawy et al., 2011) on experimental animals.

In this study, pumpkin seed oil (PSO) was used as a protective agent. Pumpkin (Cucurbita pepo) is a vegetable cultivated for human consumption and for use as functional food or medicine (Caili et al., 2006). It is rich in various antioxidants and valuable nutritional components such as essential fatty acids, amino acids, phytosterols, $\beta$-carotenes and selenium (Procida et al., 2012). Furthermore, it contains phenolic compounds such as tyrosol, vanillic acid, vanillin, ferulic acid, and luteolin (Andjelkovic et al., 2010). It has also been shown to contain high levels of tocopherol, which interpret its antioxidant activity and consequently may be able to reduce lipid peroxidation (Van Hoed et al., 2009).

Therefore, the aim of this study was to evaluate the role of PSO in alleviating the adverse effects of BPA on DNA integrity in both somatic and germ cell and histopathological changes in male mice. 


\section{Materials and Methods}

\section{Chemicals:}

Bisphenol-A (BPA) ( $\geq 99 \%$ ) was purchased from Sigma-Aldrich Company (St. Louis, MO, USA). Pumpkin seed commercial oil was purchased from EL Captin Company (Al Obour City, Cairo, Egypt). All other chemicals were of analytical grade and purchased from standard commercial suppliers.

\section{Dose preparation:}

BPA was dissolved in absolute ethyl alcohol (95\%) and diluted with corn oil [1:20 alcohol : corn oil (vehicle)] to obtain a final concentration of BPA $(50 \mathrm{mg} / \mathrm{kg}$ b.w.) and was always freshly prepared before use.

\section{Animals:}

Male Swiss albino mice weighing 26 \pm 5 g (10-12 week old) were purchased from the Theodor Bilharz Research Institute, Giza, Egypt and housed in polypropylene cages $(43 \mathrm{~cm} \times 30 \mathrm{~cm} \times 15 \mathrm{~cm}$, five mice per cage) with stainless steel covers in the Animal House of Environment and Bioagriculture Department, Faculty of Agriculture, AlAzhar University. Animals were maintained under controlled temperature $\left(23 \pm 4{ }^{\circ} \mathrm{C}\right)$, $50-55 \%$ relative humidity and a photoperiod of $12 \mathrm{~h}$ light : $12 \mathrm{~h}$ dark cycle. Food and water were given ad libitum. The animals were acclimatized for 2 weeks prior to the start of the experiments.

\section{Experimental design:}

Seventy male Swiss albino mice were randomly divided into seven groups $(n=10)$, according to approximately equal mean body weight and administered orally for 28 successive days for BPA (50 mg/kg b.w.) and/or PSO (1mL/kg b.w.) either before with or after BPA administration as follows:

group 1 (control); group 2 (vehicle); group 3 (PSO); group 4 (BPA); group 5 (PSO before BPA); group 6 (PSO with BPA) and group 7 (PSO after BPA).

\section{Oil analysis:}

\section{Fatty acids analysis:}

The methyl esters were prepared using the method prescribed by AOAC (2000). Fatty acid methyl esters (FAMEs) composition analysis was performed in an Thermo scientific TRACE 1310 gas chromatograph attached with ISQ LT single quadrupole mass spectrometer with DB1, $15 \mathrm{~m} ; 0.25 \mathrm{~mm}$ ID (J\&W scientific) capillary column. Helium was used as a carrier gas with flow rate at $1.5 \mathrm{~mL}$ min-1 and the injector temperature was maintained at $200^{\circ} \mathrm{C}$. Oven temperature was programmed with an initial temperature of $115^{\circ} \mathrm{C}$, hold for $1 \mathrm{~min}$, then increased to $280{ }^{\circ} \mathrm{C}$ by $7.5^{\circ} \mathrm{C}$ min- 1 , hold for $3 \mathrm{~min}$. The mass spectrometer detection conditions were as follows: interface temperature, $300^{\circ} \mathrm{C}$; ionization mode, EI+; electron energy, $70 \mathrm{eV}$; single ion monitoring (SIM) mode; mass range, 40-350 amu. Compounds were identified by use of NIST-library spectra and comparison of their retention times. Quantification of 14 fatty acids was accomplished by the calibration curve of fatty acid standard mixture (Sigma). 


\section{Total phenolic content:}

Total phenolic content (TPC) was determined using the Folin-Ciocalteau's reagent according to the method reported by Lin and Tang (2007) at $760 \mathrm{~nm}$ with a spectrophotometer (UV-1601; Shimadzu, Tokyo, Japan) and the quantification was done on the basis of the standard curve of gallic acid concentration ranging between 10 to $80 \mathrm{mg} / \mathrm{mL}\left(\mathrm{r}^{2}=0.99\right)$.

\section{Determination of total tocopherol (Vitamin E):}

Sample preparation was carried out based on a method described by Gimeno $\boldsymbol{e t}$ al., (2000). Determination of vitamin E was carried out using HPLC system (1100 series, Agilent Technologies) consisted of a G1311A model quaternary pump, UV detector, G1329A model automatic injector system and G1316A model thermostated column compartment). Methanol $100 \%$ was used as mobile phase at flow rate of $1.8 \mathrm{~mL}$ $\min ^{-1}$. $20 \mu \mathrm{L}$ of samples were injected into an ACE5 C18 column $(250 \times 4 \mathrm{~mm}, 5 \mu \mathrm{m}$ particle size, Advanced Chromatography Technologies., Aberdeen, Scotland) through an automatic injector system. Peaks were detected at $280 \mathrm{~nm}$ and were identified by comparing retention times of peaks for the experimental and standard sample.

\section{Measurement of antioxidant activity:}

The ability of PSO at $200 \mathrm{uL}$ to scavenge $2.9 \mathrm{~mL}$ of 1, 1'-diphenyl 1-2picrylhydrazyl (DPPH) free radical was estimated by the method of Singh et al. (2002).

\section{Evaluation of DNA damage:}

\section{1- Comet assay in cells of liver and testes:}

The comet assay was performed in liver and testes cells according to Bandyopadhyaya et al. (2008). Briefly, $50 \mu \mathrm{L}$ of cell suspension was mixed with 100 $\mu \mathrm{L}$ of $1 \%$ low melting point (LMP) agarose and added to fully frosted slides coated with $80 \mu \mathrm{L}$ of $1 \%$ normal melting point (NMP) agarose. The cells were then incubated in a lysis solution $\left(2.5 \mathrm{~mol} \mathrm{~L}^{-1} \mathrm{NaCl}, 100 \mathrm{mmol} \mathrm{L}^{-1}\right.$ EDTA, $10 \mathrm{mmol} \mathrm{L}^{-1}$ Tris-HCL, $1 \%$ Triton $\mathrm{X}-100, \mathrm{pH} \mathrm{10}$ ) at $4{ }^{\circ} \mathrm{C}$ for at least $2 \mathrm{~h}$, at which the slides were placed into an alkaline solution (300 mmol L ${ }^{-1} \mathrm{NaOH}, 1 \mathrm{mmol} \mathrm{L}^{-1}$ EDTA, pH 13) at $4{ }^{\circ} \mathrm{C}$ for $20 \mathrm{~min}$ so as to allow DNA unwinding, and electrophoresed at $25 \mathrm{~V}(300 \mathrm{~mA})$ for $20 \mathrm{~min}$. Finally, the slides were neutralized in a $400 \mathrm{mmol} \mathrm{L}^{-1}$ Tris buffer ( $\mathrm{pH} \mathrm{7.5)} \mathrm{for} 15 \mathrm{~min}$ and stained with ethidium bromide $\left(5 \mu \mathrm{g} \mathrm{mL}^{-1}\right)$. Images of 50 randomly selected nuclei per experimental group were captured using a fluorescence microscope (Eclipse 800, Nikon, Tokyo, Japan) and analyzed with image analysis software (Comet Assay IV, Perceptive Instruments, Suffolk, UK). Scored parameters included tail length, DNA percentage in tail and Olive tail moment (OTM). Tail length is the maximum distance that the damaged DNA migrates from the centre of the cell nucleus. DNA Percentage in tail is the DNA content that migrates from the nucleus into the comet tail. OTM is the product of the tail length and percentage DNA, which gives a more integrated measurement of overall DNA damage in the cell.

\section{2- Bone marrow micronucleus assay:}

The micronucleus test was carried out in mice femoral bone marrow cells according to Chauhan et al. (2000). Numbers of normochromatic, polychromatic erythrocytes and micronuclei were evaluated in control and treated groups. For micronuclei evaluation, 2000 polychromatic erythrocytes were scored per animal. Both 
normochromatic erythrocytes (NCE) and polychromatic erythrocytes (PCE) were scored in 500 erythrocytes for determination of the PCE: NCE ratio according to the OECD No. 474 guideline of mammalian erythrocyte micronucleus test for chemicals testing (OECD, 1997).

\section{Histopathological examination:}

Liver and testes from each sacrificed mouse were dissected out and trimmed of excess fat tissues. Tissues were fixed in $10 \%$ buffered formalin and processed for paraffin sectioning by dehydration in different concentrations of alcohol, cleared with xylol and embedded in paraffin blocks. Sections of about $5 \mu \mathrm{m}$ thickness were stained with Harris haematoxylin and eosin (H\&E) for histological study (Delafield, 1984).

\section{Statistical analyses:}

Statistical analyses were performed with SPSS 16 software. Experimental data were analyzed using one-way analysis of variance (ANOVA). Duncan's multiple range test was used to determine the significant differences between means. All values were expressed as mean $\pm \mathrm{SD}$ and the significance level was set at $P \leq 0.05$.

\section{Results and Discussion:}

\section{Pumpkin seed oil analyses}

The fatty acids composition, total phenolic content, vitamin $\mathrm{E}$ concentration and antioxidant activity of PSO are summarized in Table 1. The results revealed that the main fatty acids content in PSO are palmitic $(17.53 \pm 2.20)$, stearic $(7.13 \pm 0.40)$, oleic $(14.80 \pm 0.87)$ and linoleic $(58.23 \pm 2.31)$. Besides, some traces of linolenic acid $(0.87 \pm 0.30)$ and myristic $(0.43 \pm 0.15)$ were found. Furthermore, PSO phenolic and vitamin E content was $(24 \pm 1.5)$ and $(70.69 \pm 1.39)$ respectively. In addition, PSO at 200 $\mu \mathrm{L}$ exhibited an antioxidant activity of $82.13 \pm 0.57$.

Table (1): Chemical composition and antioxidant activity of pumpkin seed oil.

\begin{tabular}{|l|c|}
\hline Parameters & Value \\
\hline Fatty acids (\%) & $0.43 \pm 0.15$ \\
\hline Myristic & $17.53 \pm 2.20$ \\
\hline Palmitic & $7.13 \pm 0.40$ \\
\hline Stearic & $14.80 \pm 0.87$ \\
\hline Oleic & $58.23 \pm 2.31$ \\
\hline Linoleic & $0.87 \pm 0.30$ \\
\hline Linolenic & $24 \pm 1.5$ \\
\hline Total Phenolic Content $(\mathbf{m g}$ gallic acid /100g oil) & $70.69 \pm 1.39$ \\
\hline Vitamin E Concentration $(\boldsymbol{\mu g} / \mathbf{m L})$ & $82.13 \pm 0.57$ \\
\hline Percentage of antioxidant activity $\mathbf{( 2 0 0}$ uL) & \\
\hline
\end{tabular}




\section{DNA damage evaluation:}

\section{Comet assay in liver and testes cells:}

The comet assay results of liver and testes are summarized in Table 2. BPA induced significant increase $(P \leq 0.05)$ in the mean values of tail length, percentage of tail DNA and olive tail moment in liver and testes cells as compared to control. In contrast, administration of male mice with PSO at the three regimens with BPA diminished significantly $(P \leq 0.05)$ the increase in the mean values of comet parameters induced by BPA in liver and testes cells.

\begin{tabular}{|c|c|c|c|c|c|c|}
\hline \multirow[b]{2}{*}{ Treatments } & \multicolumn{2}{|c|}{ Tail length } & \multicolumn{2}{|c|}{$\begin{array}{c}\text { Tail DNA } \\
(\%)\end{array}$} & \multicolumn{2}{|c|}{$\begin{array}{l}\text { Olive tail moment } \\
\qquad(\mu \mathrm{m})\end{array}$} \\
\hline & Liver & Testes & Liver & Testes & Liver & Testes \\
\hline Control & $7.66 \pm 0.80^{\mathrm{e}}$ & $6.73 \pm 0.46^{\mathrm{e}}$ & $13.53 \pm 0.51^{\mathrm{c}}$ & $14.26 \pm 0.20^{\mathrm{e}}$ & $1.03 \pm 0.08^{\mathrm{d}}$ & $0.98 \pm 0.11^{\mathrm{e}}$ \\
\hline Vehicle & $8.56 \pm 0.41^{\mathrm{de}}$ & $7.26 \pm 0.30^{\text {cde }}$ & $13.15 \pm 0.22^{\mathrm{c}}$ & $15.00 \pm 0.50^{\mathrm{de}}$ & $1.12 \pm 0.04^{\mathrm{cd}}$ & $1.09 \pm 0.08^{\mathrm{de}}$ \\
\hline PSO (1 mL/kg) & $8.38 \pm 0.37^{\mathrm{e}}$ & $7.20 \pm 0.33^{\mathrm{de}}$ & $11.82 \pm 0.71^{\mathrm{d}}$ & $14.70 \pm 0.52^{\mathrm{de}}$ & $0.99 \pm 0.05^{\mathrm{d}}$ & $1.05 \pm 0.03^{\mathrm{de}}$ \\
\hline BPA (50 mg/kg) & $17.30 \pm 1.08^{\mathrm{a}}$ & $9.83 \pm 0.15^{\mathrm{a}}$ & $19.93 \pm 0.68^{\mathrm{a}}$ & $23.56 \pm 0.45^{\mathrm{a}}$ & $3.63 \pm 0.52^{\mathrm{a}}$ & $2.37 \pm 0.05^{\mathrm{a}}$ \\
\hline PSO before BPA & $9.66 \pm 0.23^{\text {cd }}$ & $7.50 \pm 0.30^{\mathrm{cd}}$ & $13.57 \pm 0.65^{\mathrm{c}}$ & $15.36 \pm 0.56^{\mathrm{cd}}$ & $1.31 \pm 0.03^{\mathrm{cd}}$ & $1.15 \pm 0.03^{\mathrm{d}}$ \\
\hline PSO with BPA & $11.80 \pm 0.50^{\mathbf{b}}$ & $8.70 \pm 0.20^{\mathbf{b}}$ & $15.36 \pm 1.02^{\mathrm{b}}$ & $17.43 \pm 0.31^{\mathbf{b}}$ & $1.85 \pm 0.08^{b}$ & $1.51 \pm 0.05^{\mathrm{b}}$ \\
\hline PSO after BPA & $10.00 \pm 0.78^{\mathrm{c}}$ & $7.83 \pm 0.40^{\mathbf{c}}$ & $14.86 \pm 0.15^{\mathrm{b}}$ & $15.80 \pm 0.26^{\mathbf{c}}$ & $1.48 \pm 0.10^{\mathrm{bc}}$ & $1.26 \pm 0.01^{\mathrm{c}}$ \\
\hline
\end{tabular}

Table (2): Comet assay parameters in liver and testes cells of treated male mice with bisphenol-A (BPA) and/or pumpkin seed oil (PSO) for 28 consecutive days.

Data are expressed as means \pm SD. Mean values in the same column within each parameter bearing the same superscript do not differ significantly $(P \leq 0.05)$.

\section{Micronucleus test:}

Results in Table 3 showed that BPA treatment increased $(P \leq 0.05)$ the mean values of micronucleated polychromatic erythrocytes (MNPCEs) significantly compared to control. In contrary, oral administration of PSO through the three regimens of treatment decreased significantly $(P \leq 0.05)$ the mean value of MNPCEs in bone marrow cells. In addition, cytotoxicity evaluation of bone marrow erythrocytes showed that BPA induced significant reduction $(P \leq 0.05)$ in the ratio of PCE/NCE as compared to control. Whereas, PSO through the three regimens of treatment has protection against BPA cytotoxicity. This protection was appeared in the elevation of the PCEs/NCEs ratio as compared with those of BPA treated group.

Our results indicated that the BPA oral administration for 28 successive days showed genotoxic and cytotoxic activity in tested cells and PSO oral administration through the three different regimens of treatment with BPA significantly ameliorated the genotoxic and cytototoxic effects of BPA.

These data are in accordance with the findings of several studies which demonstrated that BPA induced DNA damage via comet assay and micronucleus test in blood lymphocytes, rat spermatocytes and Chinese hamster ovary (CHO) cells (Tiwari et al., 2012; Wu et al. , 2013; Xin et al., 2015). 
Table (3): Frequencies of micronucleated polychromatic erythrocytes and polychromatic/normochromatic ratio in bone marrow cells of bisphenol-A (BPA) and/or pumpkin seed oil (PSO) treated male mice for 28 consecutive days.

\begin{tabular}{|c|c|c|c|c|}
\hline Treatments & MNPCEs & PCEs & NCES & $\begin{array}{c}\text { PCE/NCE } \\
\text { ratio }\end{array}$ \\
\hline Control & $10.40 \pm 2.96^{\mathrm{d}}$ & $1438.00 \pm 32.95^{\text {ab }}$ & $562.00 \pm 32.95^{\text {cd }}$ & $5.13 \pm 0.43^{\mathrm{ab}}$ \\
\hline Vehicle & $10.00 \pm 4.00^{\mathrm{d}}$ & $1434.40 \pm 57.36^{\mathrm{ab}}$ & $565.60 \pm 57.36^{\mathrm{cd}}$ & $5.13 \pm 0.75^{\mathrm{ab}}$ \\
\hline PSO (1 mL/kg) & $6.80 \pm 3.63^{\mathrm{d}}$ & $1478.80 \pm 40.53^{\mathrm{a}}$ & $521.20 \pm 40.53^{\mathrm{d}}$ & $5.70 \pm 0.62^{\mathrm{a}}$ \\
\hline BPA (50 mg/kg) & $66.40 \pm 9.94^{\mathrm{a}}$ & $1149.60 \pm 56.80^{\mathrm{d}}$ & $850.40 \pm 56.80^{\mathrm{a}}$ & $2.71 \pm 0.31^{\mathrm{d}}$ \\
\hline PSO before BPA & $18.40 \pm 4.33^{\mathrm{c}}$ & $1386.40 \pm 37.77^{\mathbf{b c}}$ & $613.60 \pm 37.77^{\mathrm{bc}}$ & $4.52 \pm 0.40^{\mathrm{bc}}$ \\
\hline PSO with BPA & $28.40 \pm 7.26^{\mathrm{b}}$ & $1330.80 \pm 60.82^{c}$ & $669.20 \pm 60.82^{\mathrm{b}}$ & $3.99 \pm 0.58^{\mathbf{c}}$ \\
\hline PSO after BPA & $20.80 \pm 6.26^{\mathrm{bc}}$ & $1364.80 \pm 59.64^{\mathrm{c}}$ & $635.20 \pm 59.64^{\mathbf{b}}$ & $4.34 \pm 0.61^{\mathrm{c}}$ \\
\hline
\end{tabular}

Data are expressed as means \pm SD. Mean values in the same column within each parameter bearing the same superscript do not differ significantly $(P \leq 0.05)$. MNPCEs: Micronucleated Polychromatic erythrocytes PCEs:

Ploychromatic erythrocites NCEs: Normochromatic erythrocytes

The mechanism of BPA genotoxicity might work through the induction of oxidative stress and the depletion of antioxidant enzymes (Meeker $\boldsymbol{e t}$ al., 2010; Jiang $\boldsymbol{e t}$ al., 2011). Beside to that, BPA is an endocrine disruptor structurally similar to estrogen, exerts a weak estrogen-like effect as well as an anti-androgenic effect (Li, 2015). It was shown that estrogen causes DNA damage by estrogen-derived oxidants, DNA adducts formed by estrogen metabolites and formation of micronuclei in cell lines (Cavalieri $\boldsymbol{e t}$ al., 2002; Mobley and Brueggemeier, 2004).

Concerning PSO treatments that alleviated the BPA induction of DNA damage in tested cells, our results are in agreement with those reported by Elfiky et al. (2012) who found that oral administration of PSO for ten consecutive days either before or after treatment of azathioprine was effective in the reduction of the frequencies of DNA fragmentation and MNPCEs frequencies, meanwhile, increased the percentage of PCEs/NCEs ratio in bone marrow of male mice. Therefore, it might suggest that the protective effects of PSO against BPA genotoxicity could be due to their content of varied bioactive compounds which were mentioned early.

Antioxidant compounds like phenolic acids, polyphenols and flavonoids scavenge free radicals such as peroxide, hydro-peroxide of lipid hydroxyl and thus inhibit the oxidative mechanisms that lead to degenerative diseases (Shahriar et al., 2012). The oil analysis in our study confirmed that PSO is rich in polyphenolics and vitamin E. Phenolic compounds have properties including antioxidant, anti-mutagenic, anticarcinogenic and anti-inflammatory effects that might potentially be beneficial in protecting the stability of the genome (Xie et al., 2013). In the same manner, polyphenolics ameliorate cell injury and protect oxidant induced DNA from lesion by reducing the free radical mediated oxidative damage (Urquiaga and Leighton, 2000). 
Meanwhile, vitamin E has an antioxidant role and can contribute to the cells protection against the deleterious effects of free radicals (Santana et al., 2015).

\section{Histopathological examination:}

Regarding the examined liver sections of BPA's treated mice; it revealed marked congestion of the hepatic blood vessels as well as marked vacuolar degeneration of the hepatocytes with many necrotic cells which appeared either with pyknotic nuclei or without any nuclear structure (Figure $\mathbf{2} \mathbf{B} \mathbf{\&} \mathbf{C}$ ). On the other hand, liver histopathological examination of PSO s treated mice for 28 successive days before BPA treatment showed good protection against BPA's hepatic cellular alteration. It revealed only mild vacuolar degeneration of the hepatocytes with some necrotic cells (Fig. 2 D). In regards to liver of PSO and BPA co-treated mice, it showed centrilobular degeneration and necrosis of the hepatocytes with appearance of increased number of binucleated cells and karyomegaly of some cells (Fig. 2 E). While, the hepatic tissue of PSO's treated mice for 28 successive days after BPA treatment showed moderated degree of granular degeneration and scattered necrotic hepatocytes (Fig. 2 F).

As for the examined testicular tissue of BPA treated mice, it showed an obvious defective spermatogenesis that characterized by severe necrosis and loss of the spermatogonial layers with multiple spermatid giant cells formation in most of the seminiferous tubules. Congestion of the interstitial blood vessel, destructed and abnormal spermatid formation with spermatid giant cells and loss of most of the spermatogonial cell layers were observed as well. Some seminiferous tubules showed destructed materials in the lumen with multiple spermatid giant cells formation were also observed (Figure 3 B \&C). Testis of PSO's treated mice before BPA treatment showed marked protection of the spermatogonial cells layers with active spermatogenesis in the lumen of some seminiferous tubules (Fig. 3 D). Whereas, testis of PSO's treated mice in concurrently with BPA showed necrosis of some spermatogonial cells with starting of active spermatogenesis in some other seminiferous tubules (Fig. 3 E). In addition, testis of PSO s treated mice after BPA treatment showed degeneration and pyknosis of some spermatognial cells with active spermatogenesis in some other tubule and notice interstitial edema (Fig. 3 F).

The evaluation of histopathological alterations in liver and testes of treated male mice basically confirmed the genetic results as well. These findings are in agreement with Korkmaz et al. (2010) who noticed hepatic necrosis and congestion in the liver of male rats treated with BPA at a dose of $25 \mathrm{mg} / \mathrm{kg} /$ day three times a week for 50 day. Moreover, Kalb et al. (2015) showed that male mice exposure to BPA (3000 $\mu \mathrm{g} / \mathrm{kg}$ b.w.) via breast milk during the breastfeeding period caused testicular degeneration and complete aplasia in some seminiferous tubules of their testes. In addition to that, Sangai and Verma, (2012) found that BPA-caused changes in the activities of ATPase in liver of mice thereby causing a reduction in ATP produced in the cell which lead to necrosis. It has been reported that BPA generate ROS that caused oxidative damage in the brain, reproductive tract and kidney of rats (Aydogan et al., 2008; Korkmaz et al., 2009). Furthermore, the great histopathological changes in testes tissues caused by BPA may be due to its estrogenic activity (Korkmaz et al., 2010). 


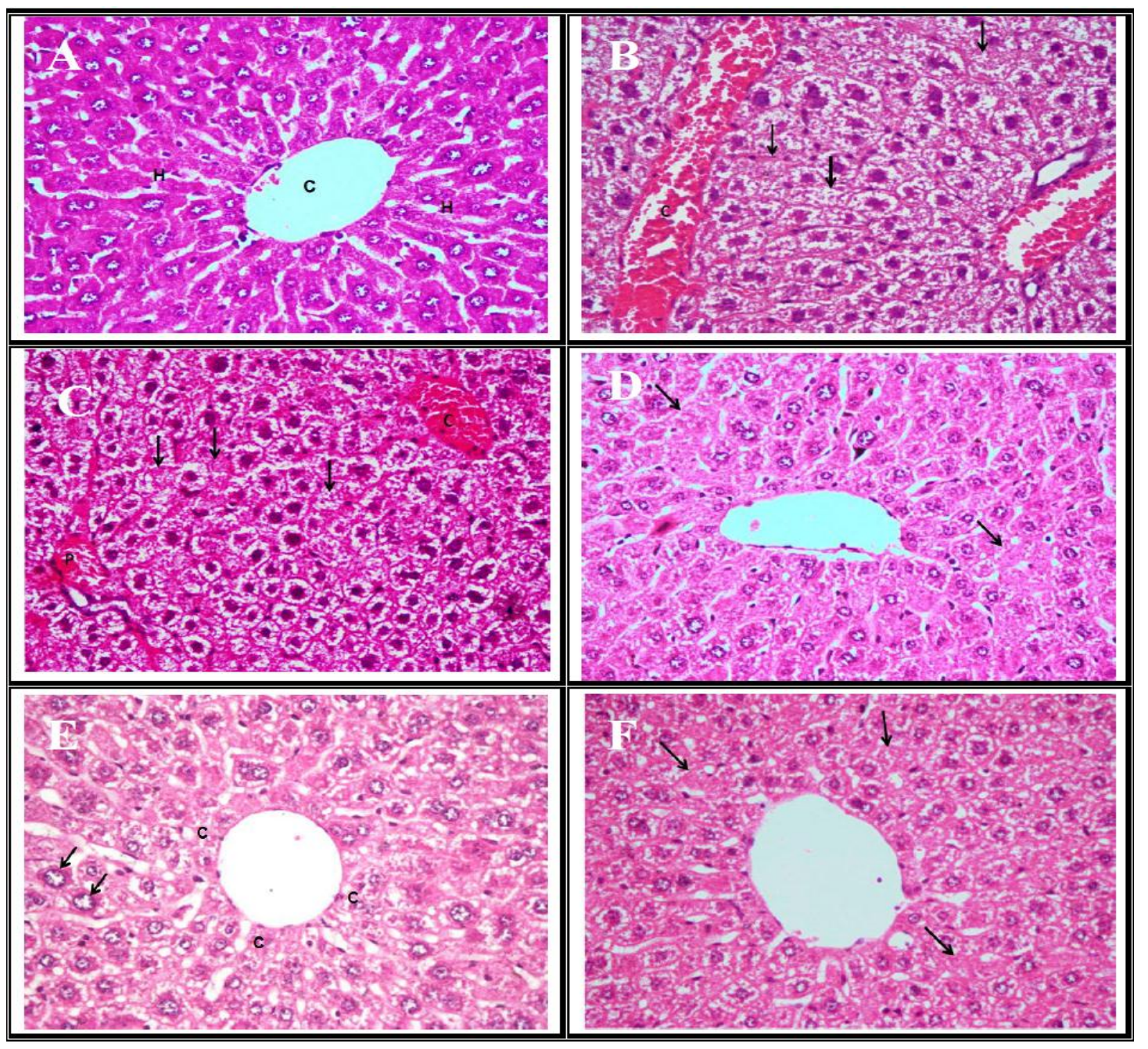

Fig. 2: A) Liver of control mice showing normal appearance of the central vein (C) and hepatic parenchyml cells $(\mathrm{H})$. B) Liver of BPA treated mice showing congestion (C) of the hepatic blood vessels and marked vacuolar degeneration of the hepatocytes with many necrotic cells (arrow). C) Liver of BPA treated mice showing congestion of the central vein (C) and portal blood vessels (P) with marked hepatocellular vacuolar degeneration and necrosis (arrow). D) Liver of PSO treated mice before BPA treatment showing mild vacuolar degeneration of the hepatocytes with some necrotic cells (arrow). E) Liver of PSO treated mice concurrently with BPA showing centrilobular degeneration (C) and necrosis of the hepatocytes, notice the karyomegaly of some cells (arrow). F) Liver of PSO treated mice after BPA treatment showing granular degeneration and scattered necrotic hepatocytes (arrow). (H\&E X400). 


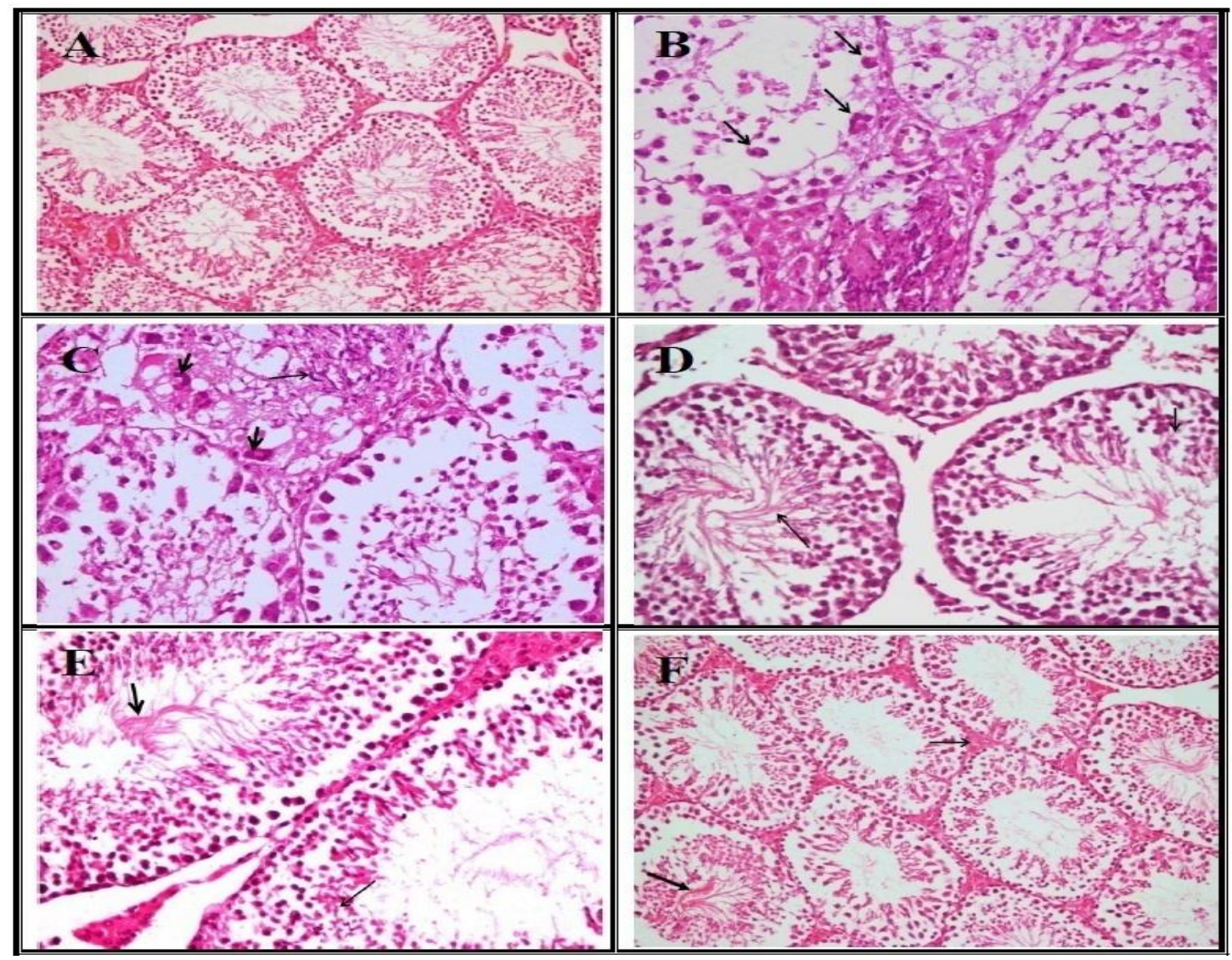

Fig. 3: A) Testis of control mice showing active spermatogenesis within most of the seminiferous tubules. B) Testis of BPA treated mice showing severe necrosis and loss of the spermatogonial layers with multiple spermatide giant cells formation (arrow) in most of the seminiferous tubules. C) Testis of BPA treated mice showing congestion of the interstitial blood vessel, destructed and abnormal spermatid formation (thin arrow), spermatid giant cells (thick arrow) and loss of most of the spermatogonial cell layers. D) Testis of PSO treated mice before BPA treatment showing marked protection of the spermatogonial cells layers with active spermatogenesis (arrow)in the lumen of some seminiferous tubules. E) Testis of PSO treated mice concurrently with BPA showing necrosis of some spermatogonial cells (thin arrow) with starting of active spermatogenesis (arrow) in some other seminiferous tubules. F) Testis of PSO treated mice after BPA treatment showing degeneration and pyknosis of some spermatognial cells with active spermatogenesis in some other tubule (arrow), notice interstitial edema (thin arrow). (H\&E X400).

On the other side, the protective role of PSO was confirmed by Ramah et al. (2015) who found that treatment with PSO markedly alleviated lead acetate induced pathological changes in testes tissues of rats.

Phenolic compounds such as polyphenols flavonoids as well as vitamins and zinc in pumpkin are attributed factors for its antioxidant activity by neutralizing free radical generation (Amara et al., 2008; Morakinyo et al., 2010). In addition, the presence of oleic acid, a monounsaturated fatty acid in pumpkin reduces the susceptibility of the testis and epididymis to lipid peroxidation (Bourre et al., 2004). 


\section{Conclusion:}

It can be concluded that BPA has the potential to produce genotoxic effects and histopathological alterations in male mice. Accordingly, strict limitations on the use of this compound must be put especially in food contact materials. On the other hand, PSO can be useful as therapeutic agent in the alleviation of the adverse effects of BPA in human.

\section{REFERENCES:}

Ahmad, S., Khan, M.B., Hoda, M.N., Bhatia, K., Haque, R., Fazili, I.S., Jamal, A., Khan, J.S. and Katare, D.P. (2012). Neuroprotective effect of sesame seed oil in 6-hydroxydopamine induced neurotoxicity in mice model: cellular, biochemical and neurochemical evidence. Neurochemical Research, 37(3): 516526.

Aikawa, H., Koyama, S., Matsuda, M., Nakahashi, K., Akazome, Y. and Mori, T. (2004). Relief effect of vitamin A on the decreased motility of sperm and the increased incidence of malformed sperm in mice exposed neonatally to bisphenol A. Cell and Tissue Research, 315: 119-124.

Amara, S., Abdelmelek, H., Garrel, C., Guiraud, P., Douki, T., Ravanat, J.L. (2008). Preventive effect of zinc against cadmiuminduced oxidative stress in the rat testis. The Journal of Reproduction and Development, 54(2): 129-134.

Andjelkovic, M., Camp, J.V., Trawka, A. and Verhe, R. (2010). Phenolic compounds and some quality parameters of pumpkin seed oil. European Journal of Lipid Science and Technology, 112: 208-217.

AOAC (2000). Association of Official Analytical Chemists. Official methods of analysis. $17^{\text {th }}$ ed. Gaithersburg, M.D. U.S.A.

Aydogan, M., Korkmaz, A., Barlas, N. and Kolankaya, D. (2008). The effect of vitamin $\mathrm{C}$ on bisphenol $\mathrm{A}$, nonylphenol and octylphenol induced brain damages of male rats. Toxicology, 249: 35-39.

Bandyopadhyaya, G., Sinha, S., Chattopadhyay, B.D. and Chakraborty, A. (2008). Protective role of curcumin against nicotine-induced genotoxicity on rat liver under restricted dietary protein. European Journal of Pharmacology, 588: 151157.

Berger, A., Ziv-Gal, A., Cudiamat, J., Wang, W., Zhou, C. and Flaws, J.A. (2016). The effects of in utero bisphenol A exposure on the ovaries in multiplegenerations of mice. Reproductive Toxicology, 60: 39-52.

Bourre, J.M., Dumont, O. and Durand, G. (2004). Dose-effect of dietary oleic acid: oleic acid is conditionally essential for some organs. Reproduction Nutrition Development, 44(4): 371-380.

Burridge, E. (2003). Bisphenol A: product profile, Eur. Chem. News., 20: 17.

Caili, F., Huan, S. and Quanhong, L. (2006). A review on pharmacological activities and utilization technologies of pumpkin. Plant Foods for Human Nutrition, 61: 73-80. 
Calafat, A.M., Ye, X., Wong, L.Y., Reidy, J.A. and Needham, L.L. (2008). Exposure of the U.S. population to bisphenol A and 4-tertiary-octylphenol: 2003-2004. Environmental Health Perspectives, 116: 39-44.

Cavalieri, E.L., Li, K.M., Balu, N., Saeed, M., Devanesan, P., Higginbotham, S., Zhao, J.M.L. and Gross, R.E.G. (2002). Catechol ortho-quinones: the electrophilic compounds that form depurinating DNA adducts and could initiate cancer and other diseases. Carcinogenesis, 23: 1071-1077.

Chauhan, L.K., Pant, N., Gupta, S.K. and Srivastava, S.P. (2000). Induction of chromosome aberrations, micronucleus formation and sperm abnormalities in mouse following carbofuran exposure. Mutatation Research, 465: 123-129.

Delafield, F. (1984). Haematoxylin and eosin for general staining. Staining of the animal tissues practical and theoretical. London, Oxford University Press.

Doherty, L., Bromer, J., Zhou, Y., Aldad, T. and Taylor, H. (2010). In utero exposure to diethylstilbestrol (DES) or bisphenol-A (BPA) increases EZH2 expression in the mammary gland: anepigenetic mechanism linking endocrine disruptors to breast cancer. Hormones and Cancer, 1(3): 148-155.

El Ghazzawy, I.F., Meleis, A.E., Farghaly, E.F. and Solaiman, A. (2011). Histological study of the possible protective effect of pomegranate juice on bisphenol-A induced changes of the caput epididymal epithelium and sperms of adult albino rats. Alexandria Journal of Medicine, 47: 125-137.

Elfiky, S.A., Elelaimy, I.A., Hassan, A.M., Ibrahim, H.M. and Elsayad, R.I. (2012). Protective effect of pumpkin seed oil against genotoxicity induced by azathioprine. The Journal of Basic and Applied Zoology, 65: 289-298.

Erler, C. and Novak, J. (2010). Bisphenol A exposure: human risk and health policy. Journal of Pediatric Nursing, 25: 400-407.

Fleisch, A.F., Sheffield, P.E., Chinn, C., Edelstein, B.L. and Landrigan, P.J. (2010). Bisphenol A and related compounds in dental materials. Pediatrics, 126: 760768.

Fu, P., Kawamura, K. (2010). Ubiquity of Bisphenol $A$ in the atmosphere. Environmental Pollution, 158: 3138-3143.

Gimeno, E., Castellote, A.I., Lamuela-Raventos, R.M., Torre, M.C. and LopezSabater, M.C. (2000). Rapid determination of vitamin E in vegetable oils by reversed phase high-performance liquid chromatography. Journal of Chromatography A, 881: 251-254.

Jiang, F., Zhang, Y. and Dusting, G.J. (2011). NADPH oxidase-mediated redox signaling: rolesin cellular stress response, stress tolerance, and tissue repair. Pharmacological Reviews, 63: 218-242.

Kalb, A.C., Kalb, A.L., Cardoso, T.F., Fernandes, C.G., Corcini, C.D., Junior, A.S.V. and Martinez, P.E. (2015). Maternal transfer of bisphenol A during nursing causes sperm impairment in male offspring. Archives of Environmental Contamination and Toxicology, 70(4): 793-801. 
Korkmaz, A., Ahab, M.A., Kolankaya, D. and Barlas, N. (2010). Influence of vitamin $\mathrm{C}$ on bisphenol A, nonylphenol and octylphenol induced oxidative damages in liver of male rats. Food and Chemical Toxicology, 48(10): 2865-2871.

Korkmaz, A., Aydoğan, M., Kolankaya, D. and Barlas, N. (2009). Vitamin C coadministration augments bisphenol A, nonylphenol, and octylphenol induced oxidative damage on kidney of rats. Environmental Toxicology, 26(4): 325-337.

Li, Y., Duan, F., Yang, F., Zhou, X., Pan, H., Li, Y. and Li, R. (2015). Pubertal exposure to bisphenol A affects the reproduction of male mice and sex ratio of offspring. Journal of Reproduction and Contraception, 26(1): 14-21.

Lin, J.Y. and Tang, C.Y. (2007). Determination of total phenolic and flavonoid contents in selected fruits and vegetables, as well as their stimulatory effects on mouse splenocyte proliferation. Food Chemistry, 101: 140-147.

Meeker, J., Calafat, A. and Hauser, R. (2010). Urinary bisphenol A concentration in relation to serum thyroid and reproductive hormones in men from an infertility clinic. Environmental Science and Technology, 44: 1458-1463.

Michalowicz, J. (2014). Bisphenol A-sources, toxicity and biotransformation. Environmental Toxicology and Pharmacology, 37: 738-758.

Mobley, J.A. and Brueggemeier, R.W. (2004). Estrogen receptor-mediated regulation of oxidative stress and DNA damage in breast cancer. Carcinogenesis, 25: 3-9.

Morakinyo, O.A., Achema, P.U. and Adegoke, O.A. (2010). Effect of zingiber officinale (Ginger) on sodium arsenite induced reproductive toxicity in male rats. African Journal of Biomedical Research, 13(1): 39-45.

OECD (1997). Test No. 474: Mammalian Erythrocyte Micronucleus Test, OECD Publishing, Paris.

Procida, G., Snatcher, B., Cateni, F. and Zaccchigna, M. (2012). Chemical composition and functional characterization of commercial pumpkin seed oil. Journal of Science and Food Agriculture, 93(5): 1035-1041.

Ramah, A., EL-shwarby, R.M., Nabila M.A. and El-shewey, E.A. (2015). The effect of lead toxicity on male albino rats reproduction with ameliorate by vitamin $\mathrm{E}$ and pumpkin seeds oil. Benha Veterinary Medical Journal, 28(1): 43-52.

Sangai, N.P. and Verma, R.J. (2012). Effect of quercetin on bisphenol A-caused alterations in succinate dehydrogenase and adenosine triphosphatase activities in liver and kidney of mice. Acta Poloniae Pharmaceutica- Drug Research, 69(6): 1189-1194.

Santana, A.T., Guelfi, M., Medeiros, H.C.D., Tavares, M.A., Bizerra, P.F.V. and Mingatto, F.E. (2015). Mechanisms involved in reproductive damage caused by gossypol in rats and protective effects of vitamin E. Biological Research, 48 (1): 43-51.

Shahriar, M., Hossain, M.I., Bahar, A.N.M., Akhter, S., Haque, M.A., and Bhuiyan, M.A. (2012). Preliminary phytochemical screening, in-Vitro antioxidant and cytotoxic activity of five different extracts of moringa oleifera leaf. Journal of Applied Pharmaceutical Science, 2(5): 65-68. 
Singh, R.P., Murthy, K.N. and Jayaprakasha, G.K. (2002). Studies on the antioxidant activity of pomegranate (Punica granatum) peel and seed extracts using in vitro models. Journal of Agricultural and Food Chemistry, 50: 81-86.

Tiwari, D., Kamble, J., Chilgunde, S., Patil, P., Maru, G., Kawle, D., Bhartiya, U., Joseph, L. and Vanage, G. (2012). Clastogenic and mutagenic effects of bisphenol A: an endocrine disruptor. Mutation Research, 743: 83-90.

Urquiaga, I. and Leighton, F. (2000). Plant polyphenol antioxidants and oxidative stress. Biological Research, 33: 55-64.

Van Hoed, V., Felkner, B., Bavec, F., Grobelnik, S., Bavec, M. and Verhe, R. (2009). Influences of processing on antioxidants content of pumpkin seed oil. $7^{\text {th }}$ Euro. Fed Lipid congress lipids fats and oils" from knowledge to application, 1018ctober, Graz. Austria.

Wu, H.J., Liu, C., Duan, W.X., Xu, S.C., He, M.D., Chen, C.H., Wang, Y., Zhou, Z., Yu, Z.P., Zhang, L. and Chen, Y. (2013). Melatonin ameliorates bisphenol Ainduced DNA damage in the germ cells of adult male rats. Mutation Research, 752: $57-67$.

Xie, C., Wang, C., Wang, X. and Yang, X. (2013). Two modified RNA extraction methods compatible with transcript profiling and gene expression analysis for cotton roots. Preparative Biochemistry and Biotechnology, 43(5): 500-511.

Xin, L., Lin, Y., Wang, A., Zhu, W., Liang, Y., Su, X., Hong, C., Wan, J., Wang, Y. and Tian, H. (2015). Cytogenetic evaluation for the genotoxicity of bisphenol-A in Chinese hamster ovary cells. Environmental Toxicology and Pharmacology, 40: 524-529.

Zeinab, K., Hassan, Z., Elobeid, M., Virk, P., Omer, S., ElAmin, M., Daghestani, M., Ebtisam, M. and Al Olayan, E. (2012). Bisphenol A induces hepatotoxicity through oxidative stress in rat model. Oxidative Medicine and Cellular Longevity, http://dx.doi.org/10.1155/2012/194829. 


\section{التأثير المحسن لزيت بذور قرع العل ضد الآثار السلبية للبيسفينول-أ في ذكور الفئران.}

\section{للسادة الدكاترة}

أ.د/ عايدة إبر اهيم المكاوي ' أ.د/ فوزي إسماعيل عيسي `د د/ محمود محمد البمبي 'أسامه حسن عبد الحميد

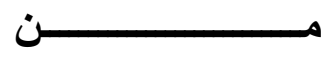

' أستاذ ور اثة الحيو ان- قسم بيولوجيا الخلية ـ شعبة الهندسة الور اثية و البيوتكنولوجى- المركز القومي للبحوث.

r أستاذ التلوث البيئي_ قسم البيئة والزر اعة الحيوية ـ كلية الزراعة بالقاهرة- جامعة الأزهر.

r أستاذ التلوث البيئي المساعد ـ قسم البيئة و الزر اعة الحيوية ـ كلية الزر اعة بالقاهرة - جامعة الأزهر

$$
\text { " مدرس مساعد- قسم البيئة و الزراعة الحيوية - كلية الزراعة بالقاهرة- جامعة الأزهر }
$$

أجريت هذه الدراسة لتقييم الدور المحسن لزيت بذور قرع العسل ضد الآثار السلبية المحتملة للبيسفينولـأ في ذكور الفئران الصغيرة. تم تجريع الفئران بالبيسفينول_أ عن طريق الفم بجرعة ــ مجم/كجم من وزن الجسم مرة و احدة يوميا لمدة ^^ يوما متتالية. بينما تم تجريع الفئران بزيت بذور قرع العسل ( مل/كجم من وزن الجسم)

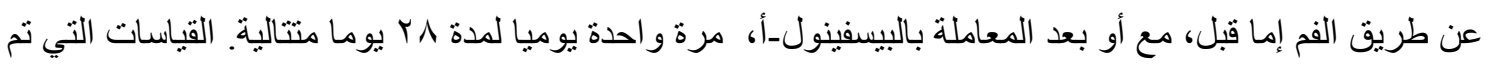
در استها كانت تقييم تلف الحامض النووى الديوكسى ريبوزى (دنا) باستخدام تقنية قياس المذنب في خلايا الكبد والخصية واختبار الأنوية الصغيرة في نخاع العظم، بالإضافة الي الفحص الهستوباثولوجي لأنسجة الكبد

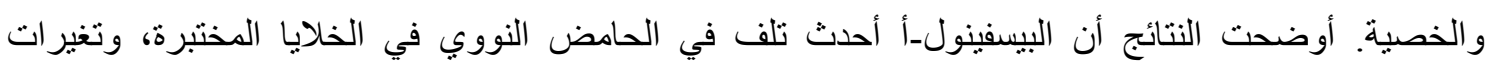

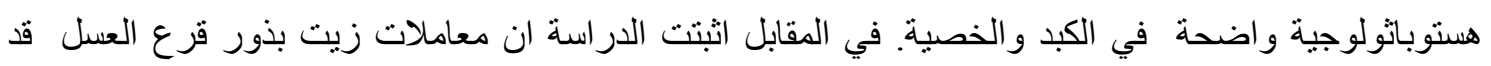
خفقت من تلف الحامض النووي وحسنت التغيرات الهستوباثولوجية في أنسجة الكبد والخصية. علاوة علي ذللك، تجريع الفئران بزيت بذور قرع العسل قبل المعاملة بالبيسفينول-أ كان أفضل نظام في تخفيف الآثار السلبية

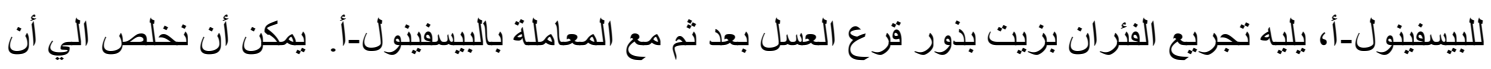
زيت بذور قرع العسل قد يكون له دور وقائي ضد السمية الوراثية و التغيرات الهستوباتولوجية للبيسفينول-أ في ذكور الفئر ان الصغيرة. مفاتيح الكلمات:

زيت بذور قرع العسل، البيسفينول_أ، السمية الجينية، الأنوية الصغيرة، ثقنية قياس المذنب، التغيرات

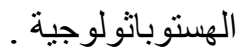

